\title{
Effects of solar ultraviolet radiation exposure on early ocean survival and fry-to-smolt growth of juvenile salmon
}

\author{
Michael C. Melnychuk ${ }^{1,4, *}$, Carl J. Walters ${ }^{1}$, Villy Christensen ${ }^{1}$, Max L. Bothwell $^{2}$, \\ David W. Welch ${ }^{3}$ \\ ${ }^{1}$ Department of Zoology and Fisheries Centre, University of British Columbia, Vancouver, British Columbia V6T 1Z4, \\ Canada \\ ${ }^{2}$ National Water Research Institute, Environment Canada, Pacific Biological Station, Nanaimo, British Columbia V9T 6N7, \\ Canada \\ ${ }^{3}$ Kintama Research Services, Nanaimo, British Columbia V9S 3B3, Canada \\ ${ }^{4}$ Present address: School of Aquatic \& Fishery Sciences, University of Washington, Seattle, Washington 98195-5020, USA
}

\begin{abstract}
Marine survival rates of many juvenile salmon populations have declined in recent decades. Although several potential causes have been proposed, there has been little conclusive evidence for which factors are responsible or not responsible for these declines. We experimentally addressed the hypothesis that exposure of coho salmon Oncorhynchus kisutch or sockeye salmon O. nerka to solar ultraviolet-B radiation (UVB) during freshwater rearing of fry and parr life-history stages increases mortality at the time of smoltification and ocean entry. Juvenile coho and sockeye salmon were reared in outdoor hatchery tanks either exposed to full spectrum sunlight or shielded from UVB radiation by plastic screens for up to 9 mo prior to release. Smolts were tagged with acoustic transmitters and detected with hydrophone receivers during their downriver and early ocean migration. Survival of treatment groups was compared using Cormack-JollySeber and Burnham mark-recapture models. While exposure to UVB resulted in decreased growth of juvenile coho salmon, survivorship during the early marine period was unaffected by the UVB treatment for both populations. This first attempt to experimentally address the hypothesis of impaired survival resulting from solar UVB radiation has shown that other factors are more likely responsible for observed declines in salmon marine survival rates.
\end{abstract}

KEY WORDS: Mortality · Salmonid · Sunlight exposure - Metabolic impairment - Migratory fish · Capture-recapture $\cdot$ Biotelemetry $\cdot$ Mobile tracking

Resale or republication not permitted without written consent of the publisher

\section{INTRODUCTION}

Many Pacific salmon populations in British Columbia, Canada, and the US Pacific Northwest have declined over the last several decades, largely as a result of lower fisheries-independent marine survival (Coronado \& Hilborn 1998, Beamish et al. 2000, Pyper et al. 2005). Large-scale geographic coherence in trends of marine (i.e. smolt-to-adult) survival and abundance suggest that factors at the regional scale are responsible for the declines (Coronado \& Hilborn 1998, Peterman et al. 1998, Welch et al. 2000, Malick et al. 2009, Teo et al. 2009; but see Bradford 1999 for exceptions in terms of covariation in smolt abundance at smaller scales). Similar trends have been observed simultaneously in Atlantic salmon Salmo 
salar on the east coast of North America (Friedland 1998). Declines occurred in both wild and hatcheryreared fish, tended to occur at southerly latitudes first and progressively move northward, and also tended to occur predominantly in rain shadow areas with resulting high exposure to sunlight (Walters \& Ward 1998).

Anadromous salmonids exhibit tremendous diversity in life history strategies. Populations exhibiting declines in marine survival and abundance were typically of species that rear in shallow streams for 1 or more years, like coho (Oncorhynchus kisutch), steelhead (O. mykiss), and stream-type Chinook (O. tshawytscha) salmon (Walters \& Ward 1998). Several possible causes of these declines have been suggested, including shifts in ocean climate regimes affecting physiological tolerance limits (Welch et al. 1998), density-dependent survival at sea due to increased hatchery smolt production (Noakes et al. 2000, Levin et al. 2001, Naish et al. 2007), disease (Arkoosh et al. 2004), freshwater habitat loss (Magnusson \& Hilborn 2003), fishing mortality (in the case of abundance), and shifts in the abundance and distribution of predators (Ware \& McFarlane 1986, Holtby et al. 1990). Food limitation in the first year of ocean life and concentrations of predators that feed on outmigrating salmon smolts at river mouths were leading hypotheses in this debate. The hypothesis of food limitation predicts that mortality should occur whenever post-smolts are faced with food shortage, either in summer (Pearcy 1992) or in winter (Beamish \& Mahnken 2001). The hypothesis of predator concentrations predicts that mortality should predominantly occur during the smolt migration, especially at river mouths, estuaries, or soon after ocean entry (Fisher \& Pearcy 1988, Greenstreet et al. 1993, Olesiuk et al. 1996, Collis et al. 2002). Most of these hypotheses are difficult if not impossible to test, as salmon usually spend several years and migrate hundreds to thousands of kilometres at sea before returning to freshwater.

One potential cause of elevated marine mortality is ultraviolet-B radiation (UVB) from sunlight during freshwater life, which could result in metabolic damage with physiological and survival consequences once juvenile salmon undergo smoltification and enter saltwater (Walters \& Ward 1998). Due to atmospheric ozone depletion at high and mid-northern latitudes (Fig. 1a), levels of incident UVB reaching the ground have gradually increased (Fig. 1b,c) over the same period as marine survival in some salmon populations has declined. These increases in UVB occurred in both summer (average 3.3 to $4.4 \%$ in- crease per decade) and winter (average 6.2 to $7.9 \%$ increase per decade) months in North America (Tarasick et al. 2003). The increases in UVB have resulted in deleterious effects on several taxa at sub-cellular, cellular, tissue and organismal levels (reviewed by Zagarese \& Williamson 2001, Häder et al. 2007), as well as on ecosystem function (Bothwell et al. 1994) and biodiversity (Kelly et al. 2003). The UVB impairment hypothesis of Walters \& Ward (1998) is not mutually exclusive with other hypotheses such as shifts in the abundance or distribution of predators, because adverse physiological effects resulting from UVB exposure might make smolts more vulnerable to predation. Ultraviolet radiation exposure has been found to affect the behaviour of juvenile salmonids in the wild (Kelly \& Bothwell 2002, Holtby \& Bothwell 2008). In the laboratory, UVB exposure effects on survival are typically dose-dependent. Some DNA damage resulting from UVB radiation can be repaired at low doses, but at higher doses, damage is irreparable and mortality ensues (Mitchell et al. 2009). Ultraviolet radiation has also been observed to impair growth (Jokinen et al. 2008) and increase oxygen consumption through increased swimming activity (Alemanni et al. 2003) of salmonids. The timing and intensity of UVB exposure during freshwater rearing may therefore be important determinants of mortality consequences.

To address the possibility that UVB exposure during freshwater rearing might result in reduced survival at the time of smoltification and ocean entry, we conducted a UVB shading experiment with 2 hatchery-reared populations during their outdoor rearing life. We evaluated possible effects on survival of fish under shaded and sunlightexposed treatments by tagging fish and estimating survival during the smolt migration using the Pacific Ocean Shelf Tracking (POST; www.postprogram.org) telemetry array (Fig. 2). Hatcheryreared Tenderfoot Creek coho salmon exhibited declines in marine survival during the 1990s (Melnychuk 2009), and are a shallow stream-rearing species in the wild. Cultus Lake sockeye salmon Oncorhynchus nerka showed pronounced declines in adult returns over time (Melnychuk 2009). Although wild juvenile sockeye are primarily lakedwelling fish with potential depth refugia from UVB exposure, their hatchery-reared counterparts are likely more susceptible to UVB. For coho, we also evaluated possible effects of sunlight or shading treatments on fry-to-smolt growth and on the concentration of UV-absorbing compounds in the epithelial mucus, as these may impact survival 

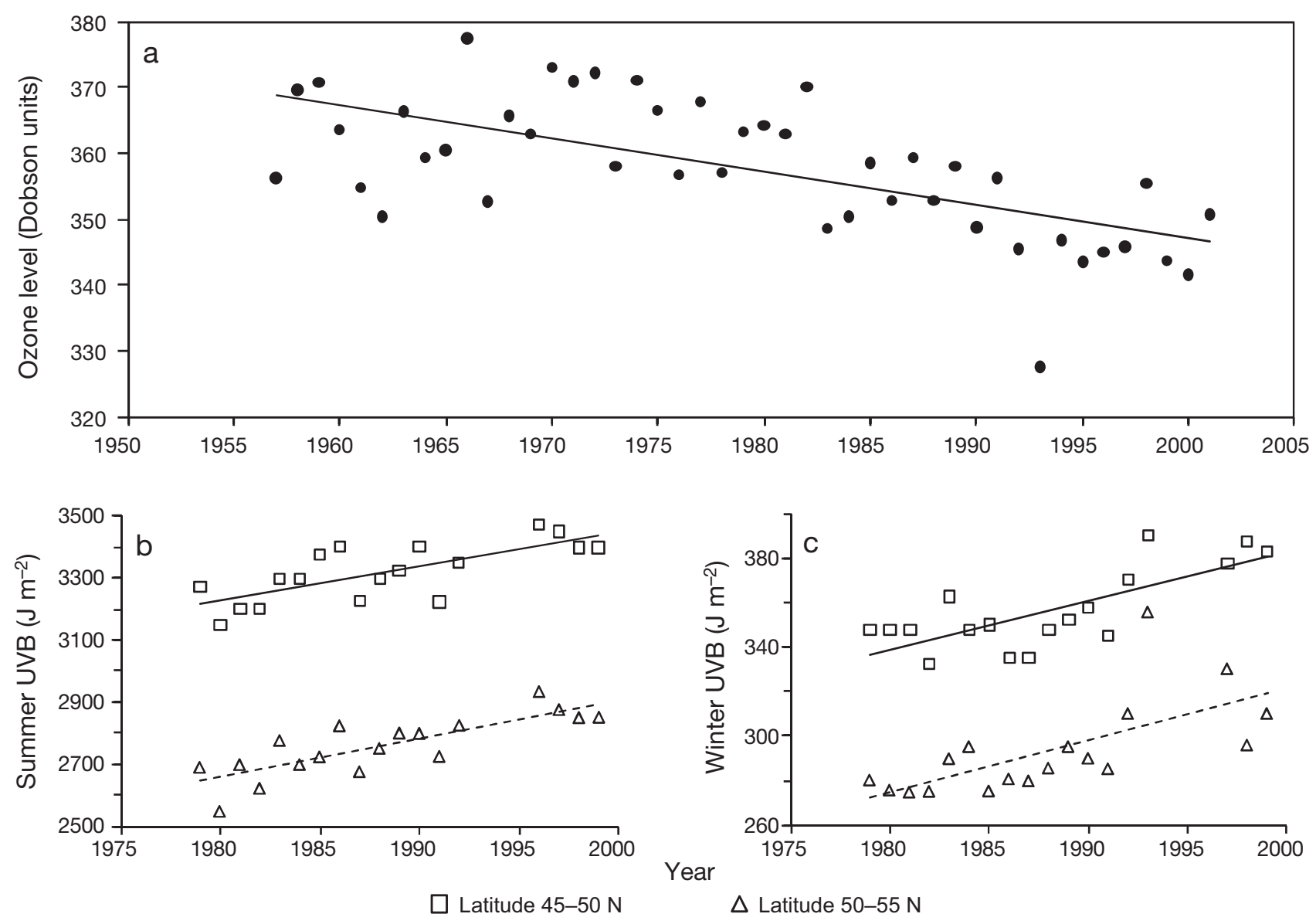

Fig. 1. Environmental data at Canadian latitudes: (a) average annual ozone levels from 1957 to 2001; ultraviolet-B radiation (UVB) during (b) summer (May to August) and (c) winter (November to February) from 1979 to 1999. Ozone data are from the Meteorological Service of Canada, measured over stations at Toronto, Ontario $\left(43^{\circ} 47^{\prime} \mathrm{N}\right)$, Edmonton, Alberta (53 $\left.33^{\prime} \mathrm{N}\right)$, Resolute, Northwest Territories $\left(74^{\circ} 43^{\prime} \mathrm{N}\right)$, Churchill, Manitoba $\left(58^{\circ} 45^{\prime} \mathrm{N}\right)$, and Goose Bay, Labrador $\left(53^{\circ} 19^{\prime} \mathrm{N}\right)$. Ozone measurements include both tropospheric (ground-level $; 10 \%$ of total column ozone) and stratospheric ( 90\%) ozone. UVB data are seasonal averages of monthly mean erythemal-action spectrum-weighted UVB exposure measurements (Tarasick et al. 2003)

indirectly. While a UVB shading experiment is logistically feasible only in a hatchery setting, any effects of UVB radiation found are expected to be similar in wild salmonids that rear in shallow freshwater streams for a year or more.

\section{MATERIALS AND METHODS}

\section{Rearing conditions}

Coho at Tenderfoot Creek Hatchery. After emergence in April 2006, production stock fry were transferred to a $1 \mathrm{~m}$ deep rearing channel. On 20 July 2006, a sample of these fish were netted and randomly distributed into either side of a divided tank (each half $\sim 3 \mathrm{~m}$ long $\times 1 \mathrm{~m}$ wide $\times 0.45 \mathrm{~m}$ deep; about 300 fish in each side). One side of the tank contained the control group, where fish were exposed to unfiltered sunlight. The other side contained fish screened from above by a DuPont-Teijin Melinex ${ }^{\circledR} 943$ plastic film (125 $\mu \mathrm{m}$ thick). This film filtered nearly $100 \%$ of UVB wavelengths but allowed photosynthetically active radiation to penetrate to the water (see Fig. S1 in the supplement at www.int-res.com/articles/suppl/m457p251_supp.pdf). The 2 groups of fish were otherwise treated identically in terms of water flowing through the tanks, feed quantity and type (Skretting Nutra Plus), and tagging procedures. These coho were exposed to, or protected from, UVB for 9 mo prior to tagging and release in May 2007. 
On 3 April 2007, a second group of coho from the production channel were transferred to experimental tanks and subjected to the same UVB exposure and shading regime for a $5 \mathrm{wk}$ period immediately prior to tagging and release (hereafter referred to as $1 \mathrm{mo}$ ). Thus, the experiment was a $2 \times 2$ crossed design, with 9 mo UVB-exposed, 9 mo UVB-shaded, 1 mo UVBexposed and 1 mo UVB-shaded treatment groups. All tagged fish were released into Tenderfoot Lake on 10 May 2007 along with the hatchery production stock.

Sockeye at Inch Creek Hatchery. Newly emerged Cultus Lake sockeye fry were transferred to 6 outdoor, small circular rearing tanks (1 m diameter) during April and May 2006. In mid-June, 3 tanks were shaded by the UVB filters and 3 tanks exposed to full spectrum sunlight (i.e. the experiment was run with the entire production stock). In mid-September, fish were aggregated into larger circular tanks (about $3 \mathrm{~m}$ diameter $\times 1 \mathrm{~m}$ deep), maintaining the same light treatments. The groundwater used at both hatcheries had very low dissolved organic carbon concentrations, so little attenuation of UVB would be expected in the shallow tanks (Kirk 1994). The same fish feed (EWOS) was used for all fish. Screening continued until smolts were tagged, shortly before their release and downstream migration in either of 2 release periods. The first group of fish was released along with most of the Cultus Lake production stock on 26 April 2007 into Sweltzer Creek. The second group was released on 16 May into Sweltzer Creek. The experiment was thus a $2 \times 2$ crossed design with UVB exposure treatments and release groups.

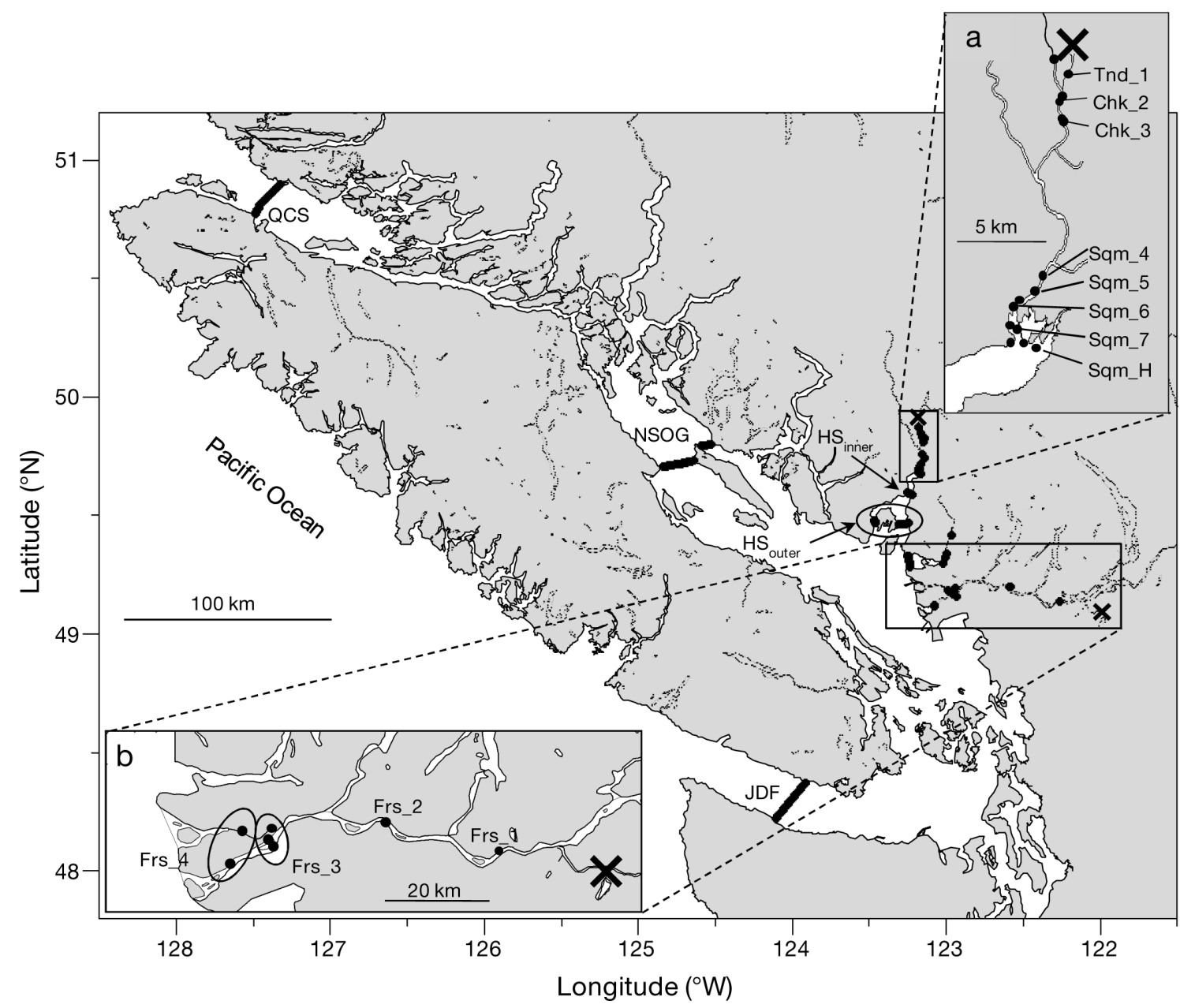

Fig. 2. Map of study area in southern British Columbia, Canada. show locations of receiver stations encountered during the 2007 migration of salmon smolts. Ocean stations are labelled in the main map: inner Howe Sound (HS inner $)$, outer Howe Sound $\left(\mathrm{HS}_{\text {outer }}\right.$ ), northern Strait of Georgia (NSOG), Queen Charlotte Strait (QCS), and the Strait of Juan de Fuca (JDF). River stations are labelled in (a) inset for Tenderfoot Creek coho (Tenderfoot Creek, Tnd; Cheakamus River, Chk; and Squamish River, Sqm stations) and in (b) inset for Cultus Lake sockeye (Fraser River stations, Frs). $\mathbf{X}=$ release sites 


\section{Smolt tagging}

At Tenderfoot Creek Hatchery, 199 coho smolts were tagged, split between UVB-exposed and UVBshaded treatments and between the 2 exposure durations (Table 1). Average body sizes were smaller in the 9 mo UVB-exposed tagging group than in the other 3 groups (Table 1 ; ANOVA, $F_{3,195}=$ $5.28, \mathrm{p}=0.002$ ). Tagged fish from all groups represented the upper end of the size distribution of fish in each tank at the end of experimental treatments (Fig. 3a). V7-2L coded acoustic tags (VEMCO) with a 30 to $90 \mathrm{~s}$ random delay between transmissions were used for all fish, with tags measuring $7 \times$ $20 \mathrm{~mm}$. Resulting tag length to body length ratios ranged from 13.6 to $16.0 \%$, adhering to the maximum recommended value of $16 \%$ by Lacroix et al. (2004). Tags were implanted into smolts using standard surgical procedures (Moore et al. 1990, Welch et al. 2007).

At Inch Creek Hatchery, 319 Cultus Lake sockeye smolts were tagged and split between UVB-exposed and UVB-shaded treatments in the first $(\mathrm{n}=119)$ and second $(\mathrm{n}=200)$ release groups. Only tagged fish were measured for length (unlike in Fig. 3a), but all fish sampled were well above the minimum threshold size of $140 \mathrm{~mm}$ for V9-6L tags (Fig. 3b; these fish were larger than typical sockeye smolts as they were part of an accelerated-growth rearing program). Lengths of tagged fish were representative of fish in the experimental tanks at the end of the treatment period, as no size-grading was involved prior to tagging. With an extra 3 wk to grow, body sizes were larger in the second release group, but average body length was similar between UVB treatments within each release period (Table 1, Fig. 3b). V9-6L acoustic tags (VEMCO), measuring $9 \times 20 \mathrm{~mm}$, were used for smolts in the first release, while V9-1L tags, measuring $9 \times 24 \mathrm{~mm}$ (with a longer battery lifespan), were used for smolts in the second release. Resulting tag to body length ratios ranged from 10.8 to $12.5 \%$ for the first release and 11.1 to $14.1 \%$ for the second release. All tags had a 30 to $90 \mathrm{~s}$ random delay between transmissions.

\section{Study sites and stationary acoustic arrays}

Cultus Lake (1.50 m annual precipitation; $179 \mathrm{~d}$ $\mathrm{yr}^{-1}$ with $\geq 0.2 \mathrm{~mm}$ precipitation) drains into Sweltzer Creek, then the Vedder River, the Sumas River, and finally the Fraser River before reaching the Strait of Georgia (Fig. 2b). Cultus Lake sockeye were released into Sweltzer Creek. They passed up to 4 acoustic receiver stations in the lower Fraser River (14 receivers deployed in 7 sub-stations; Fig. 2b). Tenderfoot Creek $(2.37 \mathrm{~m}$ annual precipitation; $193 \mathrm{~d} \mathrm{yr}^{-1}$ with $\geq 0.2 \mathrm{~mm}$ precipitation) drains into the Cheakamus River, then the Squamish River before reaching Howe Sound (Fig. 2a). Howe Sound drains into the Strait of Georgia about $40 \mathrm{~km}$ south of the river mouth. Tenderfoot coho were released into Tenderfoot Lake, the acclimation pond upstream of Tenderfoot Creek. They passed up to 8 freshwater or estuarine stations of single or paired receivers: 1 in Tenderfoot Creek, 2 in the Cheakamus River, 4 in the Squamish River, and 1 in Squamish Harbour (Fig. 2a). These lower river and estuary stations permit the partitioning of survival into freshwater and coastal marine components.

Deployment methods for ocean lines of acoustic receivers have been described elsewhere (Melny-

Table 1. Oncorhynchus kisutch and O. nerka. Release groups of Tenderfoot Creek coho salmon and Cultus Lake sockeye salmon smolts tagged in 2007 under UVB-exposed and UVB-shaded treatments and either different exposure times or different release times

\begin{tabular}{|c|c|c|c|c|c|c|}
\hline \multirow[t]{2}{*}{ Species } & \multirow{2}{*}{$\begin{array}{c}\text { UVB } \\
\text { treatment }\end{array}$} & \multirow{2}{*}{$\begin{array}{c}\text { Release date } \\
\quad(2007)\end{array}$} & \multirow{2}{*}{$\begin{array}{c}\text { Start of } \\
\text { experiment }\end{array}$} & \multicolumn{2}{|c|}{ Fork length (mm) } & \multirow{2}{*}{$\begin{array}{l}\text { Number } \\
\text { released }\end{array}$} \\
\hline & & & & Mean $\pm \mathrm{SD}$ & Range & \\
\hline \multicolumn{7}{|l|}{ Tenderfoot Creek coho } \\
\hline \multirow[t]{2}{*}{9 mo exposure duration } & Exposed & 10 May & 20 July 2006 & $129.1 \pm 2.9$ & $125-137$ & 34 \\
\hline & Shaded & 10 May & 20 July 2006 & $131.9 \pm 5.3$ & $125-146$ & 55 \\
\hline \multirow{2}{*}{1 mo exposure duration } & Exposed & 10 May & 3 April 2007 & $133.4 \pm 6.1$ & $126-147$ & 56 \\
\hline & Shaded & 10 May & 3 April 2007 & $133.2 \pm 5.7$ & $125-147$ & 54 \\
\hline \multicolumn{7}{|l|}{ Cultus Lake sockeye } \\
\hline \multirow[t]{2}{*}{ 1st release, smaller V9-6L tag } & Exposed & 26 April & 22 June 2006 & $171.5 \pm 6.0$ & $160-184$ & 61 \\
\hline & Shaded & 26 April & 22 June 2006 & $171.3 \pm 5.9$ & $160-185$ & 58 \\
\hline \multirow[t]{2}{*}{ 2nd release, larger V9-1L tag } & Exposed & 16 May & 22 June 2006 & $189.4 \pm 8.2$ & $172-208$ & 100 \\
\hline & Shaded & 16 May & 22 June 2006 & $188.1 \pm 8.3$ & $170-217$ & 100 \\
\hline
\end{tabular}


chuk et al. 2007, Welch et al. 2009). Receiver lines used for this study included those in Howe Sound (2 lines for Tenderfoot coho, $\mathrm{HS}_{\text {inner }}$ and $\mathrm{HS}_{\text {outer }}$ ), and for both populations in the northern Strait of Georgia
(NSOG), Queen Charlotte Strait (QCS) and Juan de Fuca Strait (JDF) (Fig. 2). Exit routes to the Pacific Ocean from the Strait of Georgia include Johnstone Strait and Queen Charlotte Strait to the north, and
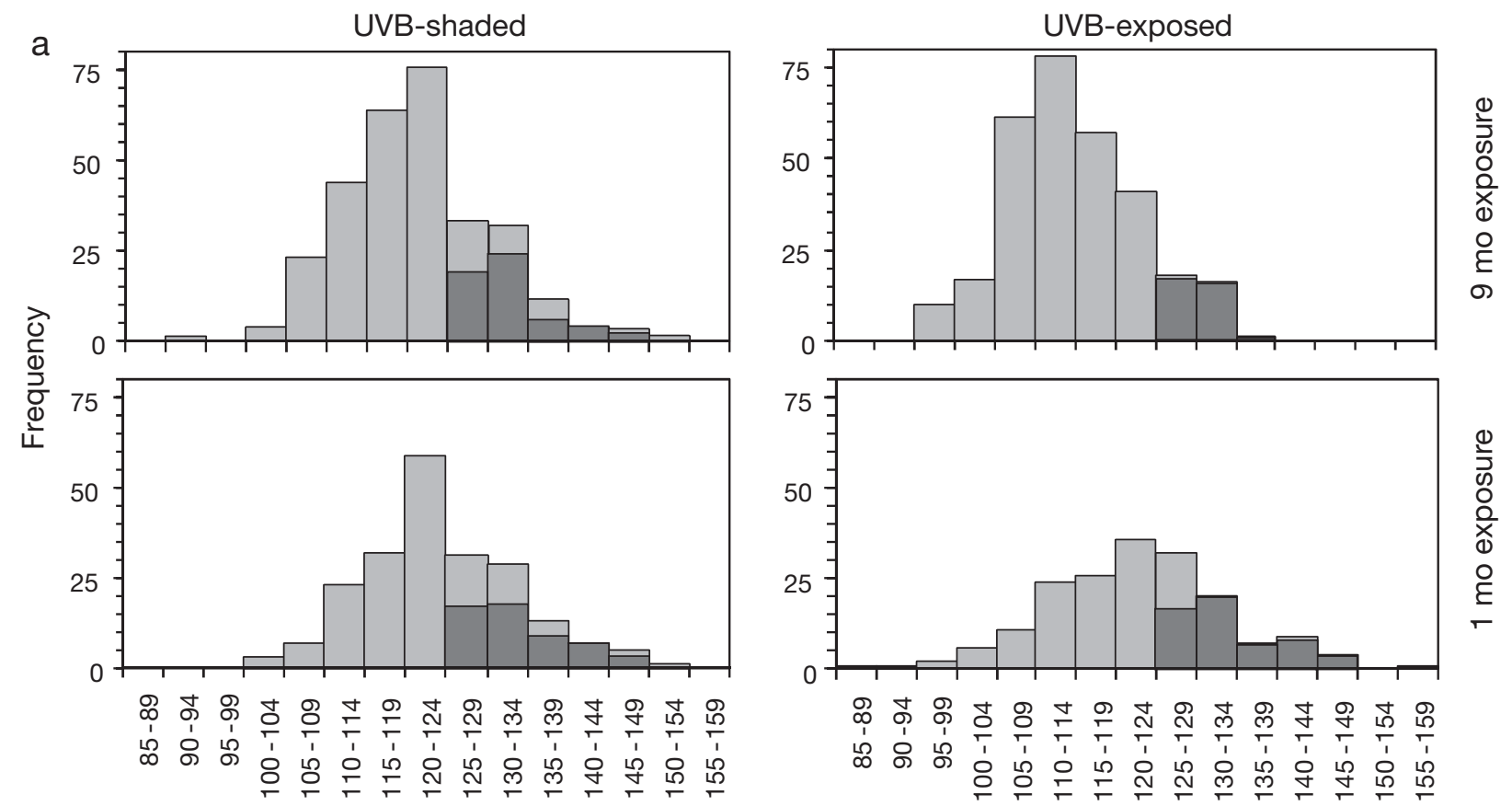

ஓ
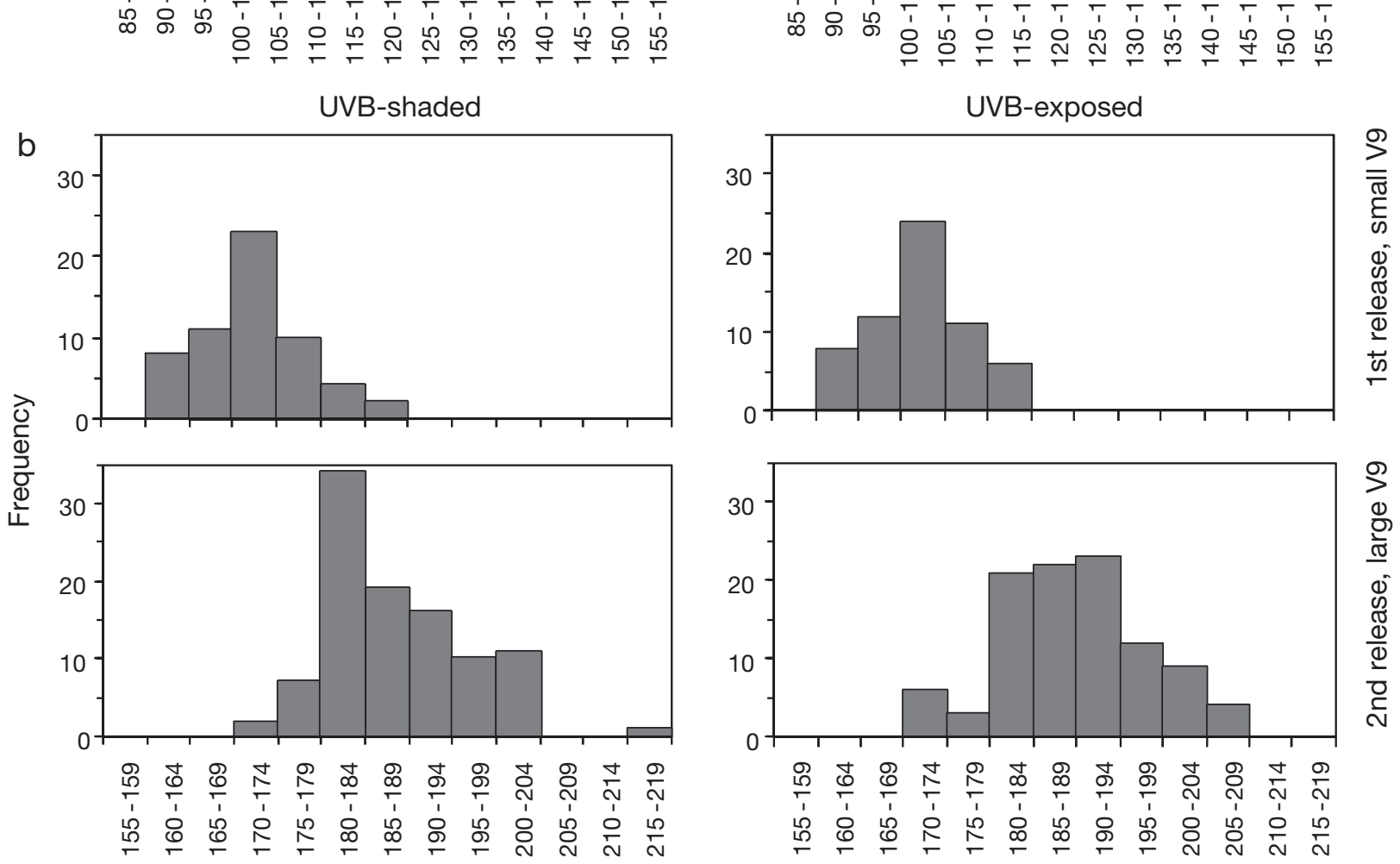

Fork length $(\mathrm{mm})$

Fig. 3. Oncorhynchus kisutch and O. nerka. Fork length distributions of 4 treatment groups of (a) Tenderfoot Creek coho and (b) Cultus Lake sockeye. Light grey bars in (a) show the lengths of fish ( $\mathrm{n}=\sim 300$ for 9 mo exposures and 200 for 1 mo exposures) in each tank at the end of the experiment and time of tagging. Dark grey bars show the subset of these fish that were tagged. In (b) only fish that were tagged were measured. Note that $x$-axes differ between (a) and (b) 
Juan de Fuca Strait to the south. Ocean receivers and Fraser River receivers were in place throughout the summer, past expected tag battery life. Cheakamus and Squamish River receivers were in place until either mid-June or mid-August, respectively, well beyond the typical migration period of Tenderfoot coho smolts observed in the years 2003 to 2006 (Melnychuk 2009).

\section{Mobile hydrophone operation}

Mobile sampling aided in quantifying the potential for differential mortality between UVB-exposed and UVB-shaded Tenderfoot coho during their migration through Howe Sound. Tagged coho smolts were tracked from a boat after they entered Howe Sound, using 2 acoustic receiver systems: a VR-28 receiver with a towed VH-40 directional hydrophone (VEMCO), and a USR-96 receiver with a towed SH-1 omni-directional hydrophone (Sonotronics). Sampling periods occurred towards the end of the migration through Howe Sound (late May to early June, $9 \mathrm{~d}$ ) and again several weeks after the migration (late July to early August, 9 d), aiming to identify locations where tags had stopped moving and were presumably lying on the seabed. Although the fates of fish carrying these stationary tags are unknown, we assume such locations represent approximate locations of mortality (Melnychuk \& Christensen 2009, Melnychuk et al. in press). Assuming a horizontal detection radius of $300 \mathrm{~m}$, about $75 \%$ of the area of Howe Sound in the first trip and $85 \%$ in the second trip was covered by mobile sampling (Fig. 4a,b). Actual detection widths were likely narrower than $300 \mathrm{~m}$, however (Melnychuk \& Christensen 2009), so the effective area covered was possibly $<50 \%$. Grid survey methods are described in Melnychuk \& Christensen (2009).

\section{UV-absorbing compounds in Tenderfoot Creek coho}

Samples for assaying the amount of UV-absorbing compounds in the epithelial mucus of the juvenile coho were collected. Fifteen non-tagged individuals from each of the 4 treatment groups were euthanized with MS-222 and the upper lobe of the caudal fin was clipped, placed on white paper with fin rays fully
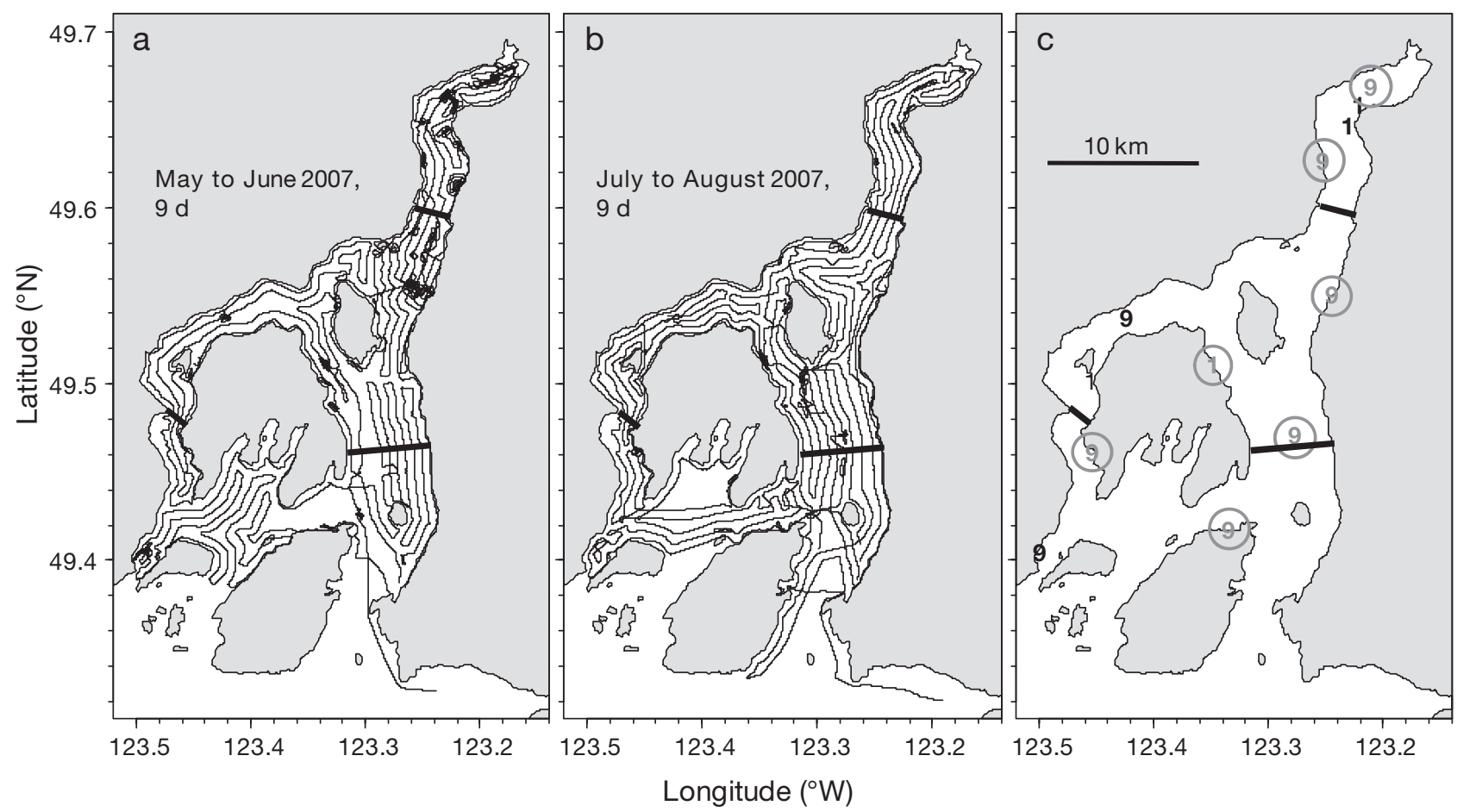

Fig. 4. Oncorhynchus kisutch. Sampling tracks in Howe Sound during (a) first and (b) second mobile tracking trips in 2007. (c) Locations in Howe Sound where 2007 coho tags stopped moving. Spacing between parallel tracks (thin lines in a and b) was $\sim 500 \mathrm{~m}$. Approximate mortality locations in (c) are shown by treatment group (9 mo UVB-shaded: 9; 9 mo UVB-exposed: 9); 1 mo UVB-shaded: 1; 1 mo UVB-exposed: (1)). Thick black lines show stationary receiver lines in Howe Sound 
extended, and photographed. The area of each fin clip was calculated from photographs using Motic Images Advanced ${ }^{\mathrm{TM}}$ image analysis software. Fin clips were frozen for later pigment extraction and assay.

Absorbance of light in the UVB range provides an index of the concentration of UVB-absorbing pigments in the tissue. Pigments in the epithelial mucus of caudal fin samples were extracted overnight in $1.9 \mathrm{ml}$ of $100 \%$ methanol in microcentrifuge tubes in the dark at $4{ }^{\circ} \mathrm{C}$ (Bothwell \& Lynch 2005; based on earlier methods of Fabacher \& Little 1995). Absorbance of the extracts was read at $295 \mathrm{~nm}$ in a $1 \mathrm{~cm}$ cuvette on an Ultraspec 3100 pro UV/Vis spectrophotometer. Absorbance readings were compared among UVB treatment and exposure duration groups in a linear regression model, using computed fin surface area as a covariate to standardize among fish with different fin sizes.

\section{Data analyses}

During the migration out of the Strait of Georgia, tagged sockeye smolts passed up to 6 detection stations, while tagged coho smolts passed up to 12 stations. In previous years, however, Tenderfoot coho were rarely detected after entering the Strait of Georgia (Melnychuk 2009). Due to the possibility of summer residency in the Strait, we limited survival inferences to the migration through Howe Sound (including the portion of the lower sound sampled by mobile tracking). We aggregated detections at the Northern Strait of Georgia, Queen Charlotte Strait, and Juan de Fuca Strait stations to represent detection anywhere after entry into the Strait of Georgia.

It was necessary to estimate detection probabilities $(p)$ at each receiver station to estimate the extent of migration of tagged fish. For Cultus Lake sockeye, we concurrently estimated survival probabilities $(\phi)$ in each segment of the migration using mark-recapture models based on the Cormack-Jolly-Seber (CJS) model (Cormack 1964, Jolly 1965, Seber 1965). For Tenderfoot Creek coho, multiple data sources were used for estimating survival, including mark-recapture data from stationary receiver lines and tagrecovery data from mobile tracking identifications of approximate mortality locations in Howe Sound. The Burnham joint live-recaptures and dead-recoveries model (Burnham 1993) was used, which incorporates both types of data. Typical assumptions of markrecapture models include independent fates of individuals and homogeneity among individuals with respect to $\phi$ and $p$, negligible effect of tags or surgeries on tagged fish, and no tag loss or failure. In spatial applications of tag-detection Cormack-JollySeber models, we also assume that detected tags are in live smolts and not in predator stomachs, and smolts do not permanently reside between successive receiver stations - they either continually migrate past receiver lines or die during the migration. Model details and further assumptions are reported elsewhere (Burnham et al. 1987, Lebreton et al. 1992). The construction of mark-recapture models for our analysis is described in the supplement (www. int-res.com/articles/suppl/m457p251_supp.pdf).

The overall hypothesis of differing survival among UVB treatment groups during the smolt migration was addressed by directly comparing candidate models, some of which included this factor and others that did not. Under this umbrella hypothesis, candidate models were treated as competing hypotheses on a more detailed level, each providing specific predictions about how survival or detection probabilities differ among UVB treatment groups and either release periods (Cultus sockeye) or exposure duration (Tenderfoot coho). Possible effects of body size on survival were explicitly evaluated by including fork length as a covariate in some models. Models were compared using QAICc (Akaike's Information Criterion corrected for overdispersion and small sample sizes; Burnham \& Anderson 2002) on the basis of their goodness-of-fit to the data and the number of parameters in the model required to achieve that fit. Detailed descriptions of the candidate models are contained in the supplement. Below, we report results from the most general model for each population and also from QAICcpreferred models.

\section{RESULTS}

Migration patterns of both populations were representative of those exhibited by multiple salmon smolt populations in southern British Columbia over $4 \mathrm{yr}$ (Melnychuk et al. 2010). Surviving Cultus Lake sockeye smolts travelled consistently from release to exit from the Strait of Georgia system, with average speeds of treatment groups ranging from 15.9 to $16.6 \mathrm{~km} \mathrm{~d}^{-1}$ for the first release and 19.8 to $21.4 \mathrm{~km} \mathrm{~d}^{-1}$ for the second release (see Fig. S3a in the supplement at www.int-res.com/articles/suppl/m457p251 _supp.pdf). Tenderfoot Creek coho smolts travelled consistently from release to the outer Howe Sound line, with average speeds of release groups ranging 


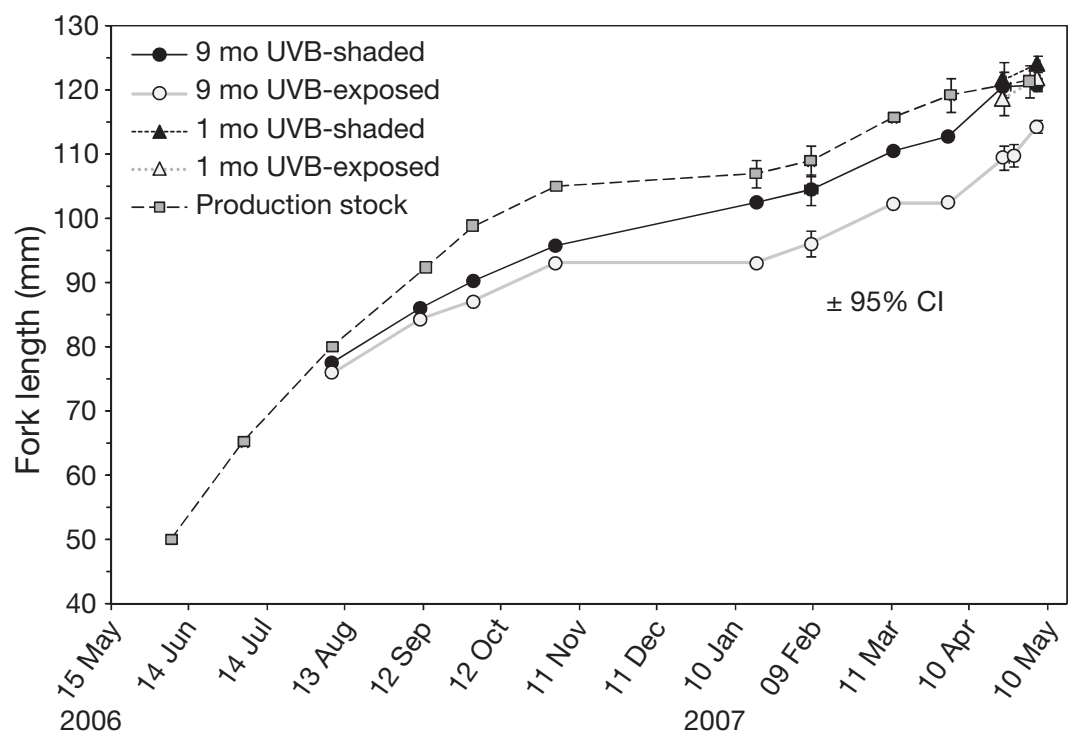

Fig. 5. Oncorhynchus kisutch. Average body size of coho treatment groups during rearing at Tenderfoot Creek Hatchery. Average lengths with $95 \%$ confidence limits (CI) were based on measurements of 50 individuals in each group, while those without error bars were based on total mass of several fish weighed together, with average mass then converted to length. UVB-shaded and UVB-exposed groups were reared in small tanks. Also shown is average fork length of the production stock, which were reared in a larger, deeper hatchery channel

from 7.1 to $9.4 \mathrm{~km} \mathrm{~d}^{-1}$ (see Fig. S3b in the supplement). There were no differences in travel speeds among UVB treatment groups within either population (Tenderfoot Creek coho from release to outer Howe Sound line, ANOVA, $F_{3,41}=0.78, p=0.51$; Cultus Lake sockeye from release to Queen Charlotte Strait or Juan de Fuca lines, first release group $t_{21}=$ $0.69, \mathrm{p}=0.50$, second release group $t_{47}=1.05, \mathrm{p}=$ 0.30 ). Thus, any differences in estimated survival probabilities among UVB treatment groups are unlikely to be attributed to travel time differences.

\section{UVB exposure effects on coho growth}

For 2 mo following the transfer of fish from the rearing channel to experimental tanks in July 2006, fish had similar average weights (and lengths) among UVB treatments (Fig. 5). By mid-January 2007, however, when fish were weighed again, the average body mass of the UVB-shaded group was greater than that of the UVB-exposed group. In February, lengths of individual fish were measured from random samples of each group, and a clear difference was observed between treatments $\left(t_{96}=5.40\right.$, $\mathrm{p}<0.001$; Fig. 5). This difference was maintained among UVB treatment groups for the remainder of spring 2007 until smolts were tagged and released.

Neither of the UVB treatment groups is a true control group with respect to the Tenderfoot Creek Hatchery production stock. Both treatment groups were reared in smaller, shallower, and lighter coloured tanks than the channel where the production stock are reared. Dorsal pigmentation differences were observed visually, with fish from both treatment groups being lighter in colour than fish from the production stock. Fish from both treatment groups were also smaller on average than fish from the production stock during most of the rearing period (Fig. 5). This margin of difference decreased between the production stock and the 9 mo UVB-shaded group during winter and spring 2007. By the time the 1 mo exposure experiment started and then by the time of tagging, all treatment groups had similar average body lengths to those of the production stock except the 9 mo UVB-exposed group, which had considerably shorter body lengths (Fig. 5).

\section{UV-absorbing compounds in Tenderfoot Creek coho}

Concentrations of UV-absorbing pigment in extracts were indirectly proportional to fin area, so analysis of covariance was used with fin area as a covariate, and exposure duration and UV treatment as additive main effects. The linear regression showed an overall effect of fin area, with an increase of 0.366 units of absorbance $( \pm 0.147 \mathrm{SE})$ for every increase of $1 \mathrm{~cm}^{2}$ of fin area $\left(F_{1,55}=6.19, \mathrm{p}=0.016\right)$. After accounting for the fin area effect, absorbance was greater for the 9 mo exposure duration groups than for the $1 \mathrm{mo}$ groups $\left(\beta_{\text {duration } / 9}=0.224 \pm 0.060 \mathrm{SE}\right.$, $\left.F_{1,55}=18.33, \mathrm{p}<0.001\right)$, but no significant difference was observed between UV treatment groups $\left(\beta_{\mathrm{UV} / \mathrm{sun}}\right.$ $=-0.084 \pm 0.059 \mathrm{SE}, F_{1,55}=2.92, \mathrm{p}=0.093$, overall intercept of $1.114 \pm 0.223$ corresponding to the $1 \mathrm{mo}$, UVB-shaded group; see Fig. S2 in the supplement). If only the 9 mo exposure groups are considered, there was again no difference in absorbance between UV treatment groups $\left(\beta_{\mathrm{UV} / \mathrm{sun}}=-0.052 \pm 0.088 \mathrm{SE}, F_{1,26}\right.$ $=0.500, \mathrm{p}=0.486$ ). 


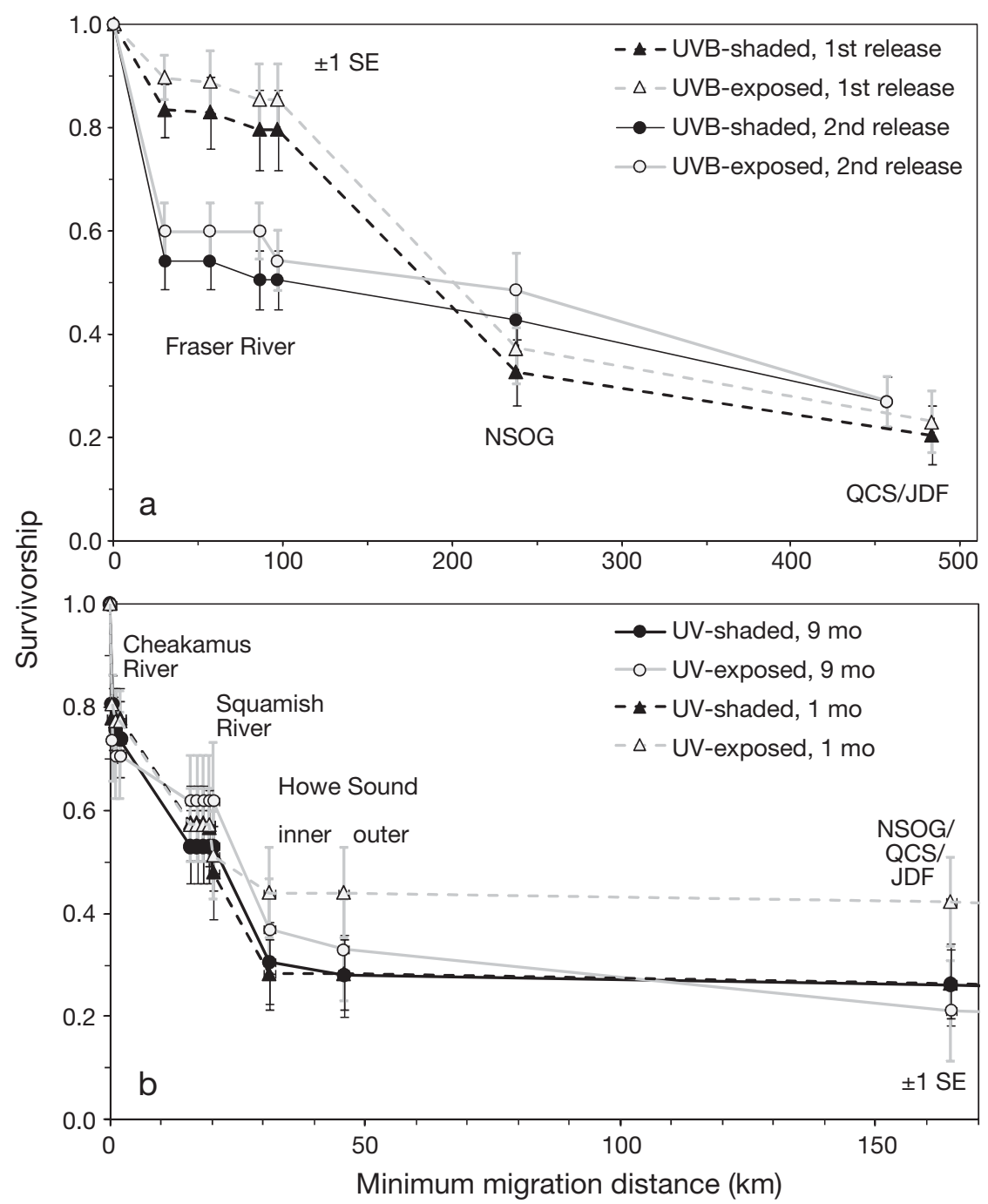

Fig. 6. Oncorhynchus nerka and O. kisutch. Survivorship curves for (a) Cultus Lake sockeye salmon from release to the Queen Charlotte Strait (QCS) or Juan de Fuca Strait (JDF) line, and (b) Tenderfoot Creek coho salmon from release to the northern Strait of Georgia (NSOG) line. Survivorship estimates are shown for each treatment group, plotted against the cumulative distance from release site to the detection station. (a) The Cormack-Jolly-Seber model for sockeye involves fully independent survival and detection probabilities for each treatment group in each segment or at each station, i.e. model $[\phi($ Seg $\times$ Rel $\times$ Treat $)$, $p$ (Station $\times$ Rel $\times$ Treat)] (see supplement at www.int-res.com/articles/suppl/ m457p251_supp.pdf for details). (b) The Burnham model for coho involves fully independent survival and detection probabilities for each treatment group in each segment or at each station, mobile tracking detection efficiencies in each Howe Sound segment that are pooled across treatment groups, and fidelity parameters fixed at 1 , i.e. model $[\mathrm{S}(\mathrm{Seg} \times$ Treat $\times$ Dur $), p($ Station $\times$ Treat $\times$ Dur $)$, $r$ (SegHS), $F(=1)]$ (see supplement for details). Error bars show \pm 1 SE. Note the different $x$-axis scales in (a) and (b)

\section{Howe Sound mobile tracking results}

In 2007, 12 motionless coho tags were located in Howe Sound, which we assumed to be approximate locations of mortality (Fig. 4c). The scattered patterns of mortality locations were similar to those observed in previous years (Melnychuk 2009, Melnychuk et al. in press). All 4 treatment groups were represented in these mortality locations, although the proportion of mortalities detected for the 9 mo UVBexposed group (6 tags out of 34 fish tagged $=17 \%$ ) was considerably higher than the proportion observed for the other 3 groups ( 2 to $6 \%$ ). In the following section, these tag-recovery data are used along with mark-recapture data from stationary receivers in a joint-model analysis of survival.

\section{Survival comparison of UVB-exposed and UVB-shaded groups}

Mark-recapture estimates of survival to successive receiver stations along the migration routes of Cultus Lake sockeye and Tenderfoot Creek coho indicate periods of high mortality in both populations, but no difference among UVB treatment groups (Fig. 6). For Cultus Lake sockeye, initial survivorship estimates differed among release periods but not among UVB treatments. Fish from the second release suffered higher mortality between release and the first Fraser River station than fish from the first release (Fig. 6a). Only a small part of this initial decline can be explained by a higher proportion of tagged fish from the second release being detected in Cultus Lake (either residualizing or having been carried into the lake by a predator; see supplement). The first release group had lower survival after ocean entry (from the Fraser River mouth to the Northern Strait of Georgia) compared to the second release. By the end of the coastal inshore migration, estimated survivorship was similar for both release groups, with no difference among UVB treatment groups (Fig. 6a).

For Tenderfoot coho, high mortality (>20\%) occurred immediately after release in all 4 treatment groups (Fig. 6b). This is likely attributable to predation in Tenderfoot Lake following the smolt release 
but before smolts started actively migrating (smolts took 1.6 to $2.2 \mathrm{~d}$ on average to travel from the hatchery to the first detection station in Tenderfoot Creek, a distance of $<400 \mathrm{~m}$ ). High mortality continued throughout the downstream migration to the first of the Squamish River stations, Sqm_4 (Fig. 2a), as well as in the first segment after ocean entry from Squamish Harbour to the inner Howe Sound line (Fig. 6b). By the end of the downstream migration there was no difference among groups in survivorship. Similarly, there was no difference among treatment groups by the time fish crossed the outer Howe Sound line (Fig. 6b and especially Fig. S4 in the supplement at www.int-res.com/articles/suppl/m457p251 _supp.pdf, which assumes a more parsimonious model). No effects of body size on survival were detected in either population. See the supplement for comparisons of candidate models which serve to evaluate the strength of evidence for an effect of UVB treatment and other factors on salmon smolt survival.

\section{DISCUSSION}

Thinning of the atmospheric ozone layer has increased levels of UVB radiation reaching the ground at temperate latitudes over the past several decades. This has resulted in deleterious ecological effects on many taxa and levels of biological organization (reviewed by Zagarese \& Williamson 2001, Häder et al. 2007). Recent studies have found behavioural differences in juvenile salmonids as a result of ultraviolet radiation exposure (Kelly \& Bothwell 2002, Holtby \& Bothwell 2008), but after Walters \& Ward (1998) proposed that UVB may be a factor responsible for declines in marine survival of streamrearing salmon populations, this hypothesis remained untested for nearly $10 \mathrm{yr}$. While UVB exposure may cause DNA damage during the shallow streamor hatchery-rearing phase of juvenile salmon, the survival consequences of this exposure may not be realized until ocean entry (Walters \& Ward 1998).

Decreased growth was observed in the 9 mo UVBexposed treatment group of Tenderfoot coho compared with the UVB-shaded group (also compared with the hatchery production stock by the end of the exposure period, at the time of smoltification; Fig. 5). This difference between treatment groups cannot be explained by size-dependent differential mortality in hatchery tanks, as few fish from any treatment died while rearing. Since treatment groups of fish were otherwise treated similarly, UVB radiation from sunlight likely caused reduced growth, although tank effects cannot be completely ruled out. This difference was established by January 2007, and maintained through smoltification. There was little overhead sunlight during autumn 2006 and winter, so the critical exposure period that led to the difference was likely the remainder of summer 2006 after 20 July (The shading experiment was initially set up on 7 June 2006, but in July 2006, the tank partition between treatment groups detached and fish intermixed. This was abandoned, and the experiment was re-started on 20 July 2006 with new fish from the rearing channel.) To note, both shaded and exposed groups initially displayed reduced growth relative to the production stock, but by the time of smoltification, average body length of the UVB-shaded group had caught up with that of the production stock (Fig. 5). The production stock was also exposed to sunlight and hence UVB, but fish were reared at a much higher density than in the experimental tanks, resulting in a higher degree of community self-shading. Fish commonly aggregated in dense formations in the rearing channel, so mean exposure to UVB would be much lower.

Other studies have found effects of UVB exposure on growth of juvenile salmonids. In Atlantic salmon, treatment with sunlight-enhanced UVB levels resulted in decreased growth and reduced immune function (plasma immunoglobulin concentration, IgM) compared with natural sunlight and UVBshaded treatments (Jokinen et al. 2008). However, they found no difference in growth or IgM in juvenile Atlantic salmon exposed to natural sunlight compared to those in UVB-shaded conditions (Jokinen et al. 2008). This might have resulted from the shorter exposure duration of their experiment (52 d in July and August 2001), a cloudier than average year in which the experiment was conducted (Jokinen et al. 2008), or the shallower angle of incident sunlight at the more northerly latitude $\left(60.9^{\circ} \mathrm{N}\right.$, Institute of Marine Research, Norway) compared with our experiment at Tenderfoot Creek Hatchery. Our finding of reduced growth in coho could result from UVB exposure causing increased oxygen consumption and swimming activity (as in a laboratory study with rainbow trout; Alemanni et al. 2003), or increased DNA-repair metabolic activity (specifically, nucleotide excision repair is an energetically expensive process used by rainbow trout Oncorhynchus mykiss in response to UVB exposure; Olson \& Mitchell 2006).

Coho smolts in the 9 mo exposure groups had a greater concentration of UVB-absorbing mycosporine-like amino acids (MAAs) in the epidermal 
mucus of fins than smolts in the 1 mo exposure groups that had recently been transferred from the production stock rearing channel. MAAs are taken up from the diet (juvenile salmon at both hatcheries were fed a diet that was largely marine-derived). Provided sufficient intake of MAAs, the concentrations of MAAs in the epithelial mucus of both freshwater and marine fishes have been shown to increase on exposure to UV radiation and are believed to confer protection from UVB (Fabacher \& Little 1995, Shick \& Dunlap 2002, Zamzow \& Losey 2002). The higher concentrations in the 9 mo groups were likely stimulated by greater overall exposure to sunlight as the density of fish and thus opportunity for finding shade was lower in the experimental tanks. Other studies have found that the stimulation of increased MAA concentration is largely in response to the UVA component of sunlight (Bothwell \& Lynch 2005), and the UVB-blocking filter we utilized allowed passage of a large portion of the UVA spectrum (see Fig. S1 in the supplement). Therefore, fish in both 9 mo groups were apparently exposed to sufficient UVA to increase the concentration of MAA. The lower levels of MAA in fish in the two 1 mo groups suggest that: (1) for these larger fish at the time of transfer to experimental tanks, this duration was insufficient to increase MAA concentration; and (2) fish in the production channel were sufficiently shielded from UV exposure so as not to develop higher MAA levels, and hence might be potentially more vulnerable to UVB after release.

The effect of UVB exposure on growth of Tenderfoot coho did not later lead to survival differences during the migration downstream and through Howe Sound. With or without accounting for the smaller average body size of the 9 mo UVB-exposed group by using fork length as a covariate (see supplement), no overall difference in survival was observed among treatment groups. Upon arrival at the outer Howe Sound line, all 4 groups had similar survivorship (Fig. 6b or see Fig. S4 in the supplement). It is not possible to make survival inferences beyond Howe Sound since Tenderfoot coho may reside in the Strait of Georgia through the summer months (Healey 1980), where they may go undetected by the more distant receiver lines.

From a conservation viewpoint, it is fortunate that survival differences were not observed in either population between UVB-exposed and UVB-shaded fish because it would be very difficult to ameliorate the consequences of a thinning ozone layer in the wild. Still, there are possible reasons why a true difference could have gone undetected:
(1) Uncertainty in the critical exposure period. The experiment at Tenderfoot Creek was re-started in mid-July 2006. If UVB exposure during late spring to mid-July of the year prior to migration to sea has survival consequences, these would have been missed in the coho experiment.

(2) Uncertainty in latency between exposure and the ensuing period of mortality. Survival was only monitored through Howe Sound for Tenderfoot coho (ca. 5 to $10 \mathrm{~d}$ post-release) and through the Strait of Georgia for Cultus Lake sockeye (ca. 25 to $30 \mathrm{~d}$ postrelease; see Fig. S3 in the supplement). Since the physiological mechanisms are not entirely clear, it is possible that UVB exposure effects may not be realized until several weeks or months after ocean entry.

(3) These experiments were conducted using available tanks at the 2 hatcheries, and such tanks may not be reflective of UVB exposure faced by the production stocks or by wild stocks. On the one hand, tank walls may have provided refugia from UVB during some hours of the day, as salmonids can see in the UVA range and likely at least to some extent in the UVB range of wavelengths (e.g. rainbow trout, Browman et al. 1994), so could have sometimes avoided ultraviolet exposure (Kelly \& Bothwell 2002). On the other hand, characteristics of natural streams such as overhead shading and deep pools may provide greater UVB protection for wild fish than that afforded in the experimental tanks or a hatchery environment in general.

Given the unambiguous lack of a survival difference between UVB treatment groups of 2 populations in controlled environments, it seems more likely that other factors are responsible for declines of marine survival rates in coho and sockeye salmon. To hedge our bets, whole life cycle confirmatory experiments could be conducted at hatcheries in sunny areas before finally dismissing the hypothesis of UVB exposure effects on salmon survival (such shading experiments would not be feasible in the wild for freely moving stream-dwelling salmonids). Coded wire tags (CWT) or passive integrative transponders (PIT, in the Columbia River) could be used to monitor the full smolt-to-adult period of hatchery-reared fish. At several hatcheries, CWT or PIT programs are already in use, so the extra marking and recapture costs would be trivial for setting up shading experiments and allocating differently coded CWTs or PIT tags among treatment groups. If any UVB effects were observed under a full approach of egg-to-smolt exposure treatments and smolt-to-adult survival assessment, then subsequent experiments could seek to identify on finer time scales when the critical peri- 
ods of UVB exposure and ensuing mortality occur. Until that time, attention should turn to other possible causal factors of elevated mortality during the vulnerable period of salmon smolt migrations.

Acknowledgements. B. Klassen, P. Campbell, S. Melville and other staff at Tenderfoot Creek Hatchery as well as A. Stobbart and other staff at Inch Creek Hatchery graciously housed the shading experiments and assisted with logistics. Kintama Research and POST members assisted with field work and logistical support. M. Jacobs, A. Ladouceur, E. Rechisky, A. Porter and P. Pawlik tagged fish. E. Rechisky assisted in setting up the shading experiment. J. Etzhorn processed tissue samples and analysed photographs. J. Frisk, N. Ban, S. Cullis-Suzuki, R. Imo, J. Jacquet, M. Bailey, K. O'Donnell, M. Darcy, W. Walters, A. Rambeau, P. Rossing, Y. Liu and E. Rechisky generously volunteered to conduct mobile transects in Howe Sound for the 2007 study. J. Petkau and 5 anonymous reviewers provided helpful comments on the manuscript. F. Goetz, M. Gregor, S. Hinch and S. Cooke graciously lent acoustic tracking equipment. M. Bradford and C. Tovey provided detection data from receivers in Cultus Lake. Grant support for field expenses was provided by the Pacific Salmon Foundation, the Canadian National Railway Company through the Cheakamus Ecosystem Restoration Technical Committee, the B.C. Pacific Salmon Forum, the Gordon \& Betty Moore Foundation, and the Alfred P. Sloan Foundation. M.C.M. was supported by a Canada Graduate Scholarship from the Natural Sciences and Engineering Research Council of Canada. This work is a contribution to the Census of Marine Life.

\section{LITERATURE CITED}

Alemanni ME, Lozada M, Zagarese HE (2003) Assessing sublethal effects of ultraviolet radiation in juvenile rainbow trout (Oncorhynchus mykiss). Photochem Photobiol Sci 2:867-870

> Arkoosh MR, Clemons E, Kagley AN, Stafford C and others (2004) Survey of pathogens in juvenile salmon Oncorhynchus spp. migrating through Pacific Northwest estuaries. J Aquat Anim Health 16:186-196

> Beamish RJ, Mahnken C (2001) A critical size and period hypothesis to explain natural regulation of salmon abundance and the linkage to climate and climate change. Prog Oceanogr 49:423-437

Beamish RJ, Noakes DJ, McFarlane GA, Pinnix W, Sweeting $\mathrm{R}$, King J (2000) Trends in coho marine survival in relation to the regime concept. Fish Oceanogr 9:114-119

Bothwell ML, Lynch DR (2005) Bioassay development for ultraviolet radiation exposure of juvenile coho salmon (Oncorhynchus kisutch). Completion report, BC Forest Science Program 2004-2005. NHRI Contribution Series No. CS-05000, Saskatoon, SK

Bothwell ML, Sherbot DMJ, Pollock CM (1994) Ecosystem response to solar ultraviolet-B radiation: influence of trophic-level interactions. Science 265:97-100

Bradford, MJ (1999) Temporal and spatial trends in the abundance of coho salmon smolts from western North America. Trans Am Fish Soc 128:840-846

> Browman HI, Novales-Flamarique I, Hawryshyn CW (1994)
Ultraviolet photoreception contributes to prey search behavior in two species of zooplanktivorous fishes. J Exp Biol 186:187-198

Burnham KP (1993) A theory for combined analysis of ring recovery and recapture data. In: Lebreton J-D, North PM (eds) Marked individuals in the study of bird population. Birkhäuser, Basel, p 199-213

Burnham KP, Anderson DR (2002) Model selection and multi-model inference: A practical information-theoretic approach. Springer, New York, NY

Burnham KP, Anderson DR, White GC, Brownie C, Pollock $\mathrm{KH}$ (1987) Design and analysis methods for fish survival experiments based on release-recapture. American Fisheries Society Monograph 5, Bethesda, MD

Collis K, Roby DD, Craig DP, Adamany S, Adkins JY, Lyons DE (2002) Colony size and diet composition of piscivorous waterbirds on the lower Columbia River: implications for losses of juvenile salmonids to avian predation. Trans Am Fish Soc 131:537-550

Cormack RM (1964) Estimates of survival from the sighting of marked animals. Biometrika 51:429-438

> Coronado C, Hilborn R (1998) Spatial and temporal factors affecting survival in coho salmon (Oncorhynchus kisutch) in the Pacific Northwest. Can J Fish Aquat Sci 55:2067-2077

Fabacher D, Little EE (1995) Skin component may protect fishes from ultraviolet-B radiation. Environ Sci Pollut Res 2:30-32

Fisher JP, Pearcy WG (1988) Growth of juvenile coho salmon (Oncorhynchus kisutch) off Oregon and Washington, USA, in years of differing coastal upwelling. Can J Fish Aquat Sci 45:1036-1044

> Friedland KD (1998) Ocean climate influences on critical Atlantic salmon (Salmo salar) life history events. Can J Fish Aquat Sci 55:119-130

> Greenstreet SPR, Morgan RIG, Barnett S, Redhead P (1993) Variation in the numbers of shags Phalacrocorax aristotelis and common seals Phoca vitulina near the mouth of an Atlantic salmon Salmo salar river at the time of the smolt run. J Anim Ecol 62:565-576

> Häder DP, Kumar HD, Smith RC, Worrest RC (2007) Effects of solar UV radiation on aquatic ecosystems and interactions with climate change. Photochem Photobiol Sci 6: 267-285

Healey MC (1980) The ecology of juvenile salmon in Georgia Strait, British Columbia. In: McNeil WJ, Himsworth DC (eds) Salmonid ecosystems of the North Pacific. Oregon State University Press, Corvallis, OR, p 203-230

Holtby LB, Bothwell ML (2008) Effects of solar ultraviolet radiation on the behaviour of juvenile coho salmon (Oncorhynchus kisutch): avoidance, feeding, and agonistic interactions. Can J Fish Aquat Sci 65:701-711

> Holtby LB, Andersen BC, Kadowaki RK (1990) Importance of smolt size and early ocean growth to interannual variability in marine survival of coho salmo (Oncorhynchus kisutch). Can J Fish Aquat Sci 47:2181-2194

Jokinen IE, Markkula ES, Salo HM, Kuhn P, Nikoskelainen S, Arts MT, Browman HI (2008) Exposure to increased ambient ultraviolet $\mathrm{B}$ radiation has negative effects on growth, condition and immune function of juvenile Atlantic salmon (Salmo salar). Photochem Photobiol 84: 1265-1271

Jolly GM (1965) Explicit estimates from capture-recapture data with both death and immigration-stochastic model. Biometrika 52:225-247 
Kelly DJ, Bothwell ML (2002) Avoidance of solar ultraviolet radiation by juvenile coho salmon (Oncorhynchus kisutch). Can J Fish Aquat Sci 59:474-482

Kelly DJ, Bothwell ML, Schindler DW (2003) Effects of solar ultraviolet radiation on stream benthic communities: an intersite comparison. Ecology 84:2724-2740

Kirk JTO (1994) Optics of UV-B radiation in natural waters. Adv Limnol 43:1-16

> Lacroix GL, Knox D, McCurdy P (2004) Effects of implanted dummy acoustic transmitters on juvenile Atlantic salmon. Trans Am Fish Soc 133:211-220

Lebreton JD, Burnham KP, Clobert J, Anderson DR (1992) Modeling survival and testing biological hypotheses using marked animals: a unified approach with case studies. Ecol Monogr 62:67-118

Levin PS, Zabel RW, Williams JG (2001) The road to extinction is paved with good intentions: negative association of fish hatcheries with threatened salmon. Proc R Soc Lond B 268:1153-1158

> Magnusson A, Hilborn R (2003) Estuarine influence on survival rates of coho (Oncorhynchus kisutch) and chinook salmon (Oncorhynchus tshawytscha) released from hatcheries on the US Pacific Coast. Estuaries 26: 1094-1103

> Malick MJ, Adkison MD, Wertheimer AC (2009) Variable effects of biological and environmental processes on coho salmon marine survival in Southeast Alaska. Trans Am Fish Soc 138:846-860

Melnychuk MC (2009) Mortality of migrating Pacific salmon smolts in southern British Columbia, Canada. PhD thesis, University of British Columbia, Vancouver

Melnychuk MC, Christensen V (2009) Methods for estimating detection efficiency and tracking acoustic tags with mobile transect surveys. J Fish Biol 75:1773-1794

Melnychuk MC, Welch DW, Walters CJ, Christensen V (2007) Riverine and early ocean migration and mortality patterns of juvenile steelhead trout (Oncorhynchus mykiss) from the Cheakamus River, British Columbia. Hydrobiologia 582:55-65

Melnychuk MC, Welch DW, Walters CJ (2010) Spatio-temporal migration patterns of Pacific salmon smolts in rivers and coastal marine waters. PLoS ONE 5:e12916

Melnychuk MC, Christensen V, Walters CJ (in press) Mesoscale movement and mortality patterns of juvenile coho salmon and steelhead trout migrating through a coastal fjord. Environ Biol Fish doi: 10.1007/s10641-012-9976-6

Mitchell DL, Adams-Deutsch T, Olson MH (2009) Dose dependence of DNA repair in rainbow trout (Oncorhynchus mykiss) larvae exposed to UV-B radiation. Photochem Photobiol Sci 8:75-81

> Moore A, Russell IC, Potter ECE (1990) The effects of intraperitoneally implanted dummy acoustic transmitters on the behaviour and physiology of juvenile Atlantic salmon, Salmo salar L. J Fish Biol 37:713-721

Naish KA, Taylor JE, Levin PS, Quinn TP, Winton JR, Huppert D, Hilborn R (2007) An evaluation of the effects of conservation and fishery enhancement hatcheries on wild populations of salmon. Adv Mar Biol 53:61-194

Noakes DJ, Beamish RJ, Sweeting R, King J (2000) Changing the balance: Interactions between hatchery and wild Pacific coho salmon in the presence of regime shifts. North Pac Anadromous Fish Comm Bull 2:155-163

Olesiuk PF, Horonowitsch G, Ellis GM, Smith TG, Flostrand
L, Warby SC (1996) An assessment of harbour seal (Phoca vitulina) predation on outmigrating chum fry (Oncorhynchus keta) and coho smolts (O. kisutch) in the lower Puntledge River, British Columbia. Pac Stock Assess Rev Comm Working Paper S95-10

Olson MH, Mitchell DL (2006) Interspecific variation in UV defense mechanisms among temperate freshwater fishes. Photochem Photobiol 82:606-610

Pearcy WG (1992) Ocean ecology of North Pacific salmonids. Washington Sea Grant Program (WSGP), Seattle

Peterman RM, Pyper BJ, Lapointe MF, Adkison MD, Walters CJ (1998) Patterns of covariation in survival rates of British Columbian and Alaskan sockeye salmon (Oncorhynchus nerka) stocks. Can J Fish Aquat Sci 55: 2503-2517

Pyper BJ, Mueter FJ, Peterman RM (2005) Across-species comparisons of spatial scales of environmental effects on survival rates of Northeast Pacific salmon. Trans Am Fish Soc 134:86-104

Seber GAF (1965) A note on the multiple recapture census. Biometrika 52:249-259

- Shick JM, Dunlap WC (2002) Mycosporine-like amino acids and related gadusols: biosynthesis, accumulation, and UV-protective functions in aquatic organisms. Annu Rev Physiol 64:223-262

Tarasick DW, Fioletov VE, Wardle DI, Kerr JB, McArthur LJB, McLinden CA (2003) Climatology and trends of surface UV radiation. Atmos-Ocean 41:121-138

Teo SLH, Botsford LW, Hastings A (2009) Spatio-temporal covariability in coho salmon (Oncorhynchus kisutch) survival, from California to southeast Alaska. Deep-Sea Res II 56:2570-2578

- Walters C, Ward B (1998) Is solar radiation responsible for declines in marine survival rates of anadromous salmonids that rear in small streams? Can J Fish Aquat Sci 55:2533-2538

Ware DM, McFarlane GA (1986) Relative impact of Pacific hake, sablefish and Pacific cod on west coast of Vancouver Island herring stocks. Int North Pac Fish Comm Bull 47:67-78

Welch DW, Ishida Y, Nagasawa K (1998) Thermal limits and ocean migrations of sockeye salmon (Oncorhynchus nerka): long-term consequences of global warming. Can J Fish Aquat Sci 55:937-948

> Welch DW, Ward BR, Smith BD, Eveson JP (2000) Temporal and spatial responses of British Columbia steelhead (Oncorhynchus mykiss) populations to ocean climate shifts. Fish Oceanogr 9:17-32

Welch DW, Batten SD, Ward BR (2007) Growth, survival, and tag retention of steelhead trout (O. mykiss) surgically implanted with dummy acoustic tags. Hydrobiologia 582:289-299

> Welch DW, Melnychuk MC, Rechisky ER, Porter AD and others (2009) Freshwater and marine migration and survival of endangered Cultus Lake sockeye salmon smolts using POST, a large-scale acoustic telemetry array. Can J Fish Aquat Sci 66:736-750

Zagarese HE, Williamson CE (2001) The implications of solar UV radiation exposure for fish and fisheries. Fish Fish 2:250-260

> Zamzow JP, Losey GS (2002) Ultraviolet radiation absorbance by coral reef fish mucus: photo-protection and visual communication. Environ Biol Fishes 63:41-47 